\title{
The 'ratione temporis' elements of self- defence
}

\section{Article}

Accepted Version

Green, J. A. (2015) The 'ratione temporis' elements of selfdefence. Journal on the Use of Force and International Law, 2 (1). pp. 97-118. ISSN 2053-1710 doi:

https://doi.org/10.1080/20531702.2015.1043097 Available at https://centaur.reading.ac.uk/39860/

It is advisable to refer to the publisher's version if you intend to cite from the work. See Guidance on citing.

Published version at: http://www.tandfonline.com/toc/rjuf20/2/1\#.Va41 nflVhBc

To link to this article DOI: http://dx.doi.org/10.1080/20531702.2015.1043097

Publisher: Hart Publishing

All outputs in CentAUR are protected by Intellectual Property Rights law, including copyright law. Copyright and IPR is retained by the creators or other copyright holders. Terms and conditions for use of this material are defined in the End User Agreement.

\section{www.reading.ac.uk/centaur}

\section{CentAUR}

Central Archive at the University of Reading

Reading's research outputs online 


\title{
THE RATIONE TEMPORIS ELEMENTS OF SELF-DEFENCE
}

\author{
JAMES A GREEN*
}

\section{INTRODUCTION}

The "inherent right" ${ }^{\prime}$ of self-defence is universally accepted as an exception to the general prohibition of the use of force. ${ }^{2}$ As a legal claim, self-defence has been ubiquitous when it comes to international uses of force, ${ }^{3}$ but while the right itself is uncontroversial its scope is, of course, highly debated. The boundaries of the right of self-defence are constantly being tested and stretched in response to new threats and challenges (actual, perceived and spurious). It is therefore of no surprise that the right has continued to receive significant academic scrutiny in recent years.

\footnotetext{
${ }^{*}$ Co-Editor-in-Chief, Associate Professor in Public International Law, University of Reading. All websites accessed 9 February 2015. The author would like to thank Sir Michael Wood and Professor Noam Lubell for their comments on an earlier version of this article, which began life as a background paper on self-defence as part of the ongoing 2010-2016 programme of work of the International Law Association's Committee on the Use of Force (of which the author is a member). He would also like to thank Dr Christian Henderson and Professor Dr Tom Ruys for their editorial comments.

${ }^{1}$ UN Charter, Article 51.

${ }^{2}$ See International Law Commission, Text of the Draft Articles on Responsibility of States for Internationally Wrongful Acts, included in the Report of the International Law Commission, 53rd session, UN Doc A/56/10, 2001, Chapter IV, www.un.org/documents/ga/docs/56/a5610.pdf, Commentary to Article 22, 177 ('the existence of a general principle admitting self-defence as an exception to the prohibition against the use of force in international relations is undisputed', emphasis added).

${ }^{3}$ See Christine Gray, International Law and the Use of Force (Oxford University Press, 3rd edn 2008), 114 ('states using force against another state almost invariably invoke self-defence,' emphasis added).
} 
This article focuses on one particular factor that is of crucial importance to all selfdefence actions. It is a factor that is almost always present in the application and appraisal of the right, but one that is not always explicitly engaged with: time. There are various ratione temporis elements underpinning the lawful exercise of the right of self-defence, and questions related to the timing of both an attack being responded to in self-defence and the response itself are notably controversial: '[a]t the beginning of the twenty-first century, the temporal boundaries of self-defence are still contentious and hard to pin down. ${ }^{4}$ Nonetheless, selfdefence has a definite 'timeline' that directly relates to assessments of the lawful exercise of the right. As Tibori Szabó has noted, the timeline of self-defence actions, "pertaining to the time before, during and...after an attack', has long been seen as crucial element of legal appraisal, '[b]oth in the Christian natural law and in the positivist conception., ${ }^{5}$

This article broadly charts the self-defence timeline, and sets out the key legal debates encountered along its trajectory. In particular, it focuses on three temporal 'stages' of the right of self-defence: 1) the much-debated ${ }^{6}$ question of preventative forms of self-defence (the 'before'); 2) the timeliness of a state's defensive action, or what is sometimes called the need for the response to be 'immediate' (the 'during'); and 3) the duration of self-defence actions, including the crucial issue of when they must end (the 'after'). In themselves, these various ratione temporis elements of the right of self-defence will be very familiar to those working in the jus ad bellum; it is worth noting that the aim of this article is not to break new

\footnotetext{
${ }^{4}$ Kinga Tibori Szabó, Anticipatory Action in Self-Defence: Essence and Limits under International Law (TMC Asser Press, 2011), 2.

${ }^{5} \mathrm{Ibid}, 81$.

${ }^{6}$ See Noam Lubell, 'The Problem of Imminence in an Uncertain World' in Marc Weller (ed), The Oxford Handbook of the Use of Force in International Law (Oxford University Press, 2015) 695, 695 ('Almost any discussion of self-defence under international law inevitably includes the debate over anticipatory selfdefence').
} 
substantive ground as such, but is, rather, to draw together these temporal strands of selfdefence in a more focussed manner than is often the case in the literature. ${ }^{7}$

\section{A BRIEF OVERVIEW OF SELF-DEFENCE}

Before considering these three points along the self-defence timeline it is first necessary to provide a brief overview of the right, and in particular to note the basic criteria for its operation. These criteria for the lawful exercise of self-defence stem from both conventional and customary international law. ${ }^{8}$ As such, the modern international legal regime concerning self-defence constitutes an amalgamation of the customary international law position (which is, of course, in a continual process of development, but which clearly stems from the preCharter customary position) and the right as it is set out in Article 51 of the UN Charter. ${ }^{9}$ Taken together, these sources of law provide the three primary criteria against which selfdefence claims must be tested (armed attack, necessity and proportionality), as well as two additional, secondary, criteria (reporting to the Security Council and the expiration of the right once the Security Council has taken action).

\section{i. Armed Attack}

\footnotetext{
${ }^{7}$ Having said this, see Terry D Gill, 'The Temporal Dimension of Self-Defence: Anticipation, Pre-Emption, Prevention and Immediacy' in Michael N Schmitt and Jelena Pejic (eds), International Law and Armed Conflict: Exploring the Faultlines: Essays in Honour of Yoram Dinstein (Martinus Nijhoff, 2007), 113.

${ }^{8}$ See Military and Paramilitary Activities in and Against Nicaragua (Nicaragua v United States of America) (merits) [1986] ICJ Reports 14, para 34.

${ }^{9}$ The amalgamation of conventional and customary international law in the context of self-defence is discussed in detail in James A Green, The International Court of Justice and Self-Defence in International Law (Hart Publishing, 2009), particularly 129-138.
} 
The notion of an 'armed attack' is an absolutely fundamental aspect of the law on selfdefence and, in the context of this article, relates in particular to the temporal issue of preventative self-defence actions. The criterion of 'armed attack' can be found in Article 51 of the UN Charter, which holds, inter alia, that: '[n]othing in the present Charter shall impair the inherent right of individual or collective self-defence if an armed attack occurs against a Member of the United Nations. ${ }^{10}$ As such, a state acting in self-defence must have suffered (or, as will be discussed below, in section III, perhaps be faced with the threat of suffering) an armed attack.

Unfortunately, though, nothing in Article 51 (or the Charter more generally) identifies exactly what an 'armed attack' is. The term 'armed attack' - used in Article 51 - differs from the phrase 'use of force' in Article 2(4), perhaps suggesting that the two concepts are not the same. ${ }^{11}$ It is commonly noted in the literature that the equally authoritative French language version of Article 51 uses the term «agression armée » (i.e., 'armed aggression') and not «attaque armée », which would seem a more accurate translation of the English. ${ }^{12}$ This serves to add to the definitional confusion over the concept, although it is also perhaps worth noting that the Spanish version, like the English, requires an «ataque armado » (a fact that is far less commonly commented upon).

In any event, the notion of an 'armed attack' as required by Article 51 has been interpreted - relatively consistently - to mean a qualitatively grave use of force. ${ }^{13}$ As the

\footnotetext{
${ }^{10}$ UN Charter, Article 51, emphasis added.

${ }^{11}$ See Yoram Dinstein, War, Aggression and Self-Defence (Cambridge University Press, 5th edn 2011), 194; and Lindsay Moir, Reappraising the Resort to Force (Hart Publishing, 2010), 22.

${ }^{12}$ See, for example, Tom Ruys, 'Armed Attack' and Article 51 of the UN Charter (Cambridge University Press, 2010), 127.

${ }^{13}$ See, for example, Olivier Corten, The Law Against War: The Prohibition on the Use of Force in Contemporary International Law (Hart Publishing, 2010), 403; Avra Constantinou, The Right of Self-Defence
} 
International Court of Justice (ICJ) famously phrased this, an armed attack constitutes 'the most grave form of the use of force' ${ }^{14}$ An assessment of state practice, both prior to and since the ICJ's formalisation of this conception in 1986, supports the view that the term 'armed attack' refers to a grave use of force. ${ }^{15}$ Therefore, a violation of Article 2(4) is not necessarily also an armed attack for the purposes of Article 51. The responding state must have faced (or perhaps be about to face) an attack of a 'grave' level, beyond that of a 'mere' use of force. Of course, this begs the question 'how grave is grave?', with the answer being determined in a context-specific manner based on the facts surrounding any given claim of self-defence. ${ }^{16}$

\section{ii. Necessity and Proportionality}

In addition to the conventional criterion of an armed attack, two further crucial requirements for lawful self-defence can be identified in customary international law: the response taken must be both necessary and proportional. These criteria are particularly important in relation

under Customary International Law and Article 51 of the UN Charter (Bruylant, 2000), 57; and Gray (n 3) 147148. Though for a contrary view, see Elizabeth Wilmshurst (ed), 'The Chatham House Principles of International Law on the Use of Force by States in Self-Defence' (2006) 55 International and Comparative Law Quarterly 963, 966; and Tarcisio Gazzini, The Changing Rules on the Use of Force in International Law (Manchester University Press, 2005), 138.

${ }^{14}$ Nicaragua (n 8) para 191. This statement was also reiterated in Case Concerning Oil Platforms (Islamic Republic of Iran v United States of America) (merits) [2003] ICJ Reports 161, para 51.

${ }^{15}$ For a detailed assessment of this state practice, see Green (n 9) 112-129.

${ }^{16}$ See Keiichiro Okimoto, The Distinction and Relationship between Jus ad Bellum and Jus in Bello (Hart Publishing, 2011), 46-51, particularly at 50-51. The necessary 'gravity' to constitute an armed attack is thus a context-specific requirement. For example, in relation to so-called 'on-the-spot-reaction' in self-defence - say, where a border patrol is ambushed - a lower-level attack may be viewed as being sufficiently 'grave' to allow for a forcible response, given the circumstances in question. See Dinstein (n 11) 242-244; and Ruys (n 12) 181. 
to the ratione temporis elements of self-defence because - as will be discussed below temporal restrictions of the right often have their roots in necessity, proportionality, or both of these customary requirements.

The necessity and proportionality criteria appeared on the landscape of 'modern' international law with a much-quoted letter of 1842 by the then United States Secretary of State, Daniel Webster, concerning the 1837 sinking of the steamship Caroline. ${ }^{17}$ Webster insisted in his exchange with Lord Ashburton, the British representative to the United States, that a state claiming self-defence must:

[S]how a necessity of self-defence, instant, overwhelming, leaving no choice of means, and no moment for deliberation. It will be for it to show, also, that...[it] did nothing unreasonable or excessive; since the act justified by the necessity of self-defence must be limited by that necessity, and kept clearly within it. ${ }^{18}$

\footnotetext{
${ }^{17}$ See Michael Byers, 'Terrorism, the Use of Force and International Law After 11 September' (2002) 51 International and Comparative Law Quarterly 401, 159 (arguing that 'the modern law of self-defence was born' with the Caroline incident). However, it is important to note that the criteria of necessity and proportionality existed in international legal theory well before the time of the Caroline: see, for example, Emerich de Vattel, Le droit des gens, ou principes de la loi naturelle, appliqués a la conduite et aux affaires des nations et des souverains, Vol. III, Charles G Fenwick (translator), in James Brown Scott (ed), The Classics of International Law (Carnegie Institution of Washington, 1916), 305.

${ }^{18}$ Letter dated 27 July 1842, from Daniel Webster to Lord Ashburton (1841-1842) XXX British and Foreign
} State Papers193-194, extract taken from Webster's earlier letter to Henry S Fox dated 24 April 1841, (18401841) XXIX British and Foreign State Papers 1137-1138, 1137-1138. 
This 'Caroline formula' is often cited with reference to preventative forms of self-defence, ${ }^{19}$ but it is actually more important to note that the concepts of necessity and proportionality in a general sense - applicable to all self-defence actions - can clearly be discerned from the formula ('a necessity of self-defence'/'nothing unreasonable or excessive'). Since the time of the Caroline, these criteria have crystallised into binding norms of customary international law through cumulative state practice and opinio juris. ${ }^{20}$ It is now undeniable that all actions of self-defence must be both necessary and proportional. ${ }^{21}$

With regard to the necessity criterion, it has occasionally been argued that this requires that the action being responded to must be of a nature as to threaten fundamentally

${ }^{19}$ See, for example, Arthur Eyffinger, 'Self-Defence or the Meanderings of a Protean Principle', in Arthur Eyffinger, Alan Stephens and Sam Muller (eds), Self-Defence as a Fundamental Principle (Hague Academic Press, 2009), 103, 119-120; Rosalyn Higgins, Problems and Process: International Law and How We Use It (Oxford University Press, 1994), 242; Noam Lubell, Extraterritorial Use of Force Against Non-State Actors (Oxford University Press, 2010), particularly 56-59; and Gregory A Raymond and Charles W Kegley, Jr, 'Preemption and Preventative War', in Howard M Hensel (ed), The Legitimate Use of Force: The Just War Tradition and the Customary Law of Armed Conflict (Ashgate, 2008), 99, 101.

${ }^{20}$ For a detailed examination of the developmental process of these criteria from their appearance in Webster's letter to elements of modern customary international law, see James A Green, 'Docking the Caroline: Understanding the Relevance of the Formula in Contemporary Customary International Law Concerning SelfDefence' (2006) 14 Cardozo Journal of International and Comparative Law 429.

21 Stanimir A Alexandrov, Self-Defence Against the Use of Force in International Law (Kluwer Law International, 1996), 20; Judith Gardam, Necessity, Proportionality and the Use of Force by States (Cambridge University Press, 2004), particularly at 6 and 11; Christine Gray, 'The Use of Force in the International Legal Order', in Malcom D Evans (ed), International Law (Oxford University Press, 3rd edn 2010) 615, 625; and Oscar Schachter, 'Implementing Limitations on the Use of Force: The Doctrine of Proportionality and Necessity: Remarks' (1992) 86 American Society of International Law Proceedings 39. 
the survival of the state invoking self-defence. ${ }^{22}$ However, analysis of state practice/opinio juris clearly confirms that nothing as devastating as a threat to a state's survival is required before a defensive response can be seen as being legally necessary. ${ }^{23}$ In fact, the necessity criterion as it operates today requires that the responding state show that that the extremity of the situation meant that it would have been wholly unreasonable to expect the responding state to attempt non-forcible measures of resolution. ${ }^{24}$ In other words, a forcible response must be a 'last resort' in the sense that there existed no practical or reasonable alternative to it (not that there was absolutely no alternative at all). ${ }^{25}$ The necessity criterion does not procedurally require that other measures - negotiation, for example - must first be attempted, although where such an attempt is made and yet fails this may be indicative of the necessity of a forcible response. ${ }^{26}$ Ultimately, force must be the only reasonable option for a state to take to abate an armed attack.

Turning to the proportionality requirement, a common misconception is that it refers to an equivalence of scale and/or means between the attack being responded to and the response. ${ }^{27}$ However, this 'tit-for-tat' conception of proportionality is not reflected in state practice, nor does it represent the majority view in academic commentary. Instead, the

\footnotetext{
${ }^{22}$ See, for example, Georg Schwarzenberger, 'The Fundamental Principles of International Law' (1955) 87 Recueil Des Cours 9, 97.

${ }^{23}$ Dinstein (n 11) 187.

${ }^{24}$ This interpretation of the necessity criterion can be discerned from the state practice, see Green (n 20) 450457; and Ruys (n 12) 95-98.

${ }^{25}$ See Myra Williamson, Terrorism, War and International Law: The Legality of the Use of Force against Afghanistan in 2001 (Ashgate, 2009) 115.

${ }^{26}$ See Dinstein (n 11) 232; and Green (n 9) 80-85.

${ }^{27}$ See David Kretzmer, 'The Inherent Right of Self-Defence and Proportionality in Jus ad Bellum' (2013) 24 European Journal of International Law 235, 237 (noting, but not subscribing to, this understanding of proportionality).
} 
requirement of proportionality refers to the need for the state to act in a manner that is proportional to the established defensive necessity. This means that the proportionality criterion is not merely a requirement for a numerical equivalence of scale or means, but rather that the force employed must not be excessive with regard to the goal of abating or repelling the attack being responded to. A state can use whatever force is required (in terms of scale and/or means) to abate the attack against it, but no more. ${ }^{28}$

Finally, it is important to keep in mind that the criteria of necessity and proportionality are both extremely flexible and context-specific criteria that are based, to an extent, on nebulous notions of 'acceptability' and 'reasonableness'. ${ }^{29}$ The necessity or proportionality of any given defensive use of force will be inherently dependant on the circumstances at hand and, as a result, the criteria lack certainty. ${ }^{30}$ Much depends on whether other states accept a claim by the state exercising the right that its response was reasonably taken as last resort and was not excessive in relation to that need to act.

\section{iii. Additional Criteria for Self-Defence}

It should be noted that on top of the three primary criteria of armed attack, necessity and proportionality, there are two other secondary legal requirements for the exercise of selfdefence. Both of these additional requirements are set out in Article 51 and concern the interrelationship between the right of self-defence and the collective security mechanism set

\footnotetext{
${ }^{28}$ See, for example, the 'Chatham House Principles', Wilmshurst (ed) (n 13) 968-969; Gardam (n 21 ) 142 and 161; Green (n 9) 86-96, and Ruth Wedgwood, 'Proportionality and Necessity in American National Security Decision Making' (1992) 86 American Society of International Law Proceedings 58, 59.

${ }^{29}$ On the flexibility of these criteria, see Gardam (n 21) 21.

${ }^{30}$ See Richard R Baxter, 'The Legal Consequences of the Unlawful Use of Force under the Charter' (1968) 62 American Society of International Law Proceedings 68, 74.
} 
up by the UN Charter and, thus, the relationship between self-defence and the UN Security Council.

First, Article 51 provides that: '[m]easures taken by members in the exercise of this right of self-defence shall be immediately reported to the Security Council. ${ }^{31}$ However, this obligation is of a material nature, in that it is generally accepted that a failure to report does not in itself turn an otherwise lawful use of force in self-defence into an unlawful one. ${ }^{32}$ Secondly, Article 51 also holds that the right of self-defence can be exercised only 'until the Security Council has taken measures necessary to maintain international peace and security'. ${ }^{33}$ This so-called 'until clause', ${ }^{34}$ which requires that the defending state must desist in its forcible action once the Security Council has taken action in response to the armed attack against it, will be briefly discussed in section V.

\section{Before the Attack: Preventative Responses}

The first ratione temporis element of the right of self-defence relates to the period of time before the armed attack being responded to has even occurred. This section deals with the

\footnotetext{
${ }^{31}$ UN Charter, Article 51. For a detailed appraisal of the reporting requirement, see James A Green, 'The Article 51 Reporting Requirement for Self-Defense Actions' (2015) Virginia Journal of International Law, forthcoming. A pre-publication version of this article is available on the Social Science Research Network $(S S R N)$ (2 September 2014), http://ssrn.com/abstract=2572406.

${ }^{32}$ See Dinstein (n 11) 239-241; Gazzini (n 13) 154-155; Green (n 31) 40-46 (SSRN version); and D W Greig, 'Self-Defence and the Security Council: What Does Article 51 Require?' (1991) 40 International and Comparative Law Quarterley 366, 387-388. See also Nicaragua (n 8) paras 200. For a contrary view, see Derek W Bowett, Self-Defence in International Law (Manchester University Press, 1958), 197-199.

${ }^{33}$ UN Charter, Article 51.

${ }^{34}$ A term used, for example, by Ruys (n 12) 74.
} 
controversial issue of self-defence in response to the threat of attack (be it actual or merely perceived), rather than to an attack that has taken place. This is the best-known, and by far the most discussed, temporal issue relating to self-defence: what the layman would call the question of a 'pre-emptive strike'.

\section{i. Terminology}

It is worth noting from the outset that the terminology with regard to this avowed manifestation of self-defence is not at all uniform in the literature. Various terms are used inconsistently by different scholars to mean different things in this context. ${ }^{35}$ This terminological uncertainty adds further confusion to the already rather poorly delineated concept of self-defence in response to a threatened attack. To try to ensure clarity, therefore, this article adopts following terminology: 'anticipatory self-defence' is used to refer to action taken in response to an imminent attack, while 'pre-emptive self-defence' is employed to refer to action taken in response to a perceived threat of attack that is more temporally remote. The term 'preventative self-defence' is used to refer to any form of forcible action taken before an actual attack has commenced (i.e., as a 'catch all' for any use of force launched in response to an attack that has not yet occurred). Finally, the conception of 'interceptive self-defence' will be briefly noted: this term has been used by some writers to denote force taken in response to an attack that has 'begun' but has not yet reached or affected the victim state. ${ }^{36}$ These various terminological choices are entirely arbitrary; other writers will have other preferences. ${ }^{37}$ Nonetheless, they will be used consistently here.

\footnotetext{
${ }^{35}$ Something pointed out by Gray (n 3) 211-212.

${ }^{36}$ Dinstein (n 11) 203-205.

${ }^{37}$ The terminology used herein is employed in the same way by both Constantine Antonopoulos, 'Force by Armed Groups as Armed Attack and the Broadening of Self-Defence' (2008) 55 Netherlands International Law Review 159, 172; and Niaz A Shah, 'Self-Defence, Anticipatory Self-Defence and Pre-Emption: International
} 


\section{ii. The Core Debate}

There exist deep divisions amongst both states and scholars as to the lawfulness of any form of preventative self-defence. The issue has long been an academic hot potato - indeed, one so hot that it has essentially been burnt to a crisp - and the divisions over it are not likely to be resolved any time soon. At the core of the debate is the question of whether an actual attack must have 'occurred' before a response can be taken, or whether the pre-existing customary manifestation of the right (allowing for force to be used against a threat) has survived the adoption of the UN Charter.

Those that take the former position (sometimes termed 'restrictionists ${ }^{38}$ ) point to the fact that, as a matter of simple textual analysis, Article 51 is quite clear that an armed attack must have occurred. ${ }^{39}$ They then support this interpretation of the law by reference to the fact that relatively few states have advanced a preventative justification for using force post1945 and, even when they have, such claims have commonly been rejected by other states. ${ }^{40}$

Law's Response to Terrorism' (2007) 12 Journal of Conflict and Security Law 95, 111. However, their decision in this regard is just as arbitrary as the present author's: Deeks, for example, uses the same terms as those used herein, but to denote different things. See Ashley S Deeks, 'Taming the Doctrine of Pre-Emption' in Marc Weller (ed), The Oxford Handbook of the Use of Force in International Law (Oxford University Press, 2015) 661, 668-663.

${ }^{38}$ This term for that group of scholars is used, for example, by Christian Henderson, The Persistent Advocate and the Use of Force: The Impact of the United States upon the Jus ad Bellum in the Post-Cold War Era (Ashgate, 2010), 173.

${ }^{39}$ The classic example of this view is Ian Brownlie, International Law and the Use of Force by States (Oxford University Press, 1963), particularly at 275-278. See also Corten (n 13) 407-411.

${ }^{40}$ See, for example, Gray (n 3) particularly at 160-165. 
In contrast, those supporting preventative self-defence - sometime called 'expansionists" ${ }^{41}$ (or a variation on that moniker) - argue that the use of force taken in response to a threat was lawful under the pre-charter custom (pointing, often, to Caroline), ${ }^{42}$ and that Article 51 explicitly preserves a state's 'inherent right' of self-defence. ${ }^{43}$ It has also been noted by some in this camp that Article 51 says that self-defence is lawful if an armed attack occurs, but not 'if and only if an armed attack occurs'. ${ }^{44}$ Other expansionists, eschewing such dubious linguistic gymnastics, rather more convincingly point out that the equally authoritative French version of Article 51 is seemingly less restrictive in this regard than the English, in that it refers more generally to a UN member as being 'the object' of armed aggression, rather than an armed attack 'occurring' as such: "dans le cas où un Membre des Nations Unies est l'objet d'une agression armée ». ${ }^{45}$ Finally, but perhaps most crucially, the expansionist position is further justified by reference to the fact that it is illogical for a state to wait until the 'hammer falls' on it, if it is clearly evident that said hammer is raised to strike. This argument gains particular potency when one considers the nature of modern weaponry and delivery systems. ${ }^{46}$

\footnotetext{
41 Again, this term is used by Henderson (n 38) 173. The classic example of this view is Bowett (n 32) particularly at 188-192.

${ }^{42}$ See (n 19) and accompanying text.

${ }^{43}$ Rosalyn Higgins, 'The Attitudes of Western States towards Legal Aspects of the Use of Force', in Antonio Cassese (ed), The Current Legal Regulation of the Use of Force (Martinus Nijhoff, 1986), 435, 442.

${ }^{44}$ See Nicaragua (n 8) dissenting opinion of Judge Schwebel, para 173 for the most famous expression of this view. See also, Bowett (n 32) 188.

45 A point made by Rosalyn Higgins, The Development of International Law Through the Political Organs of the United Nations (Oxford University Press, 1963), 199; and C Humphrey Waldock, 'The Regulation of the Use of Force by Individual States in International Law' (1952) 81 Recueil Des Cours 451, 497.

${ }^{46}$ Deeks (n 37) 669-675; Higgins (n 19) 242-243; and Lubell (n 19) 57.
} 


\section{iii. Anticipatory Self-Defence: Responses to Imminent Attacks}

Preventative self-defence in all forms remains highly controversial, but those who do support the concept usually employ a criterion of imminence as a vital part of any attempt to establish the lawfulness of such action. ${ }^{47}$ The idea of self-defence against an imminent attack - what is herein termed 'anticipatory self-defence' - famously echoes the Caroline formula, which held that self-defence can only be exercised in situations where the need to respond is 'instant...leaving...no moment for deliberation., 48

When preventative self-defence in response to a threat has been advanced as a justification by states post-1945, other states have in a number of cases accepted or rejected this claim based on whether the perceived threat of attack was imminent. ${ }^{49}$ It may equally be said, though, that there are notable examples of states rejecting any kind of preventative action as being unlawful per se, irrespective of whether the threatened attack was imminent. ${ }^{50}$ The state practice locus classicus on this remains Israel's attack on Iraq's Osiraq nuclear reactor in June 1981. Here, Israel explicitly justified its action as anticipatory self-defence. ${ }^{51}$ Taking the restrictionist standpoint, one can point to the fact that states almost universally condemned the attack on Osiraq, ${ }^{52}$ and a number did so on the basis that self-defence against

\footnotetext{
${ }^{47}$ See, for example, Bowett (n 32) 187-193; Henderson (n 38) 171-193; Lubell (n 19) 55-63; and Raymond and Kegley (n 19) particularly at 101-109.

${ }^{48}$ Letter of 27 July 1842 (n 18) 1138.

${ }^{49}$ For a discussion of this state practice, see Green (n 9) 96-98.

${ }^{50}$ See ibid, 98 .

${ }^{51}$ See, inter alia, UN Doc S/PV.2288 (19 June 1981), 32.

${ }^{52}$ Twenty five states addressed letters of condemnation regarding the attack to the President of the Security Council (these documents can be found within the symbol range UN Doc S/14531 - S/14560).
} 
a threatened armed attack is unlawful per se. ${ }^{53}$ In contrast, from the expansionist perspective, it is notable that Israel itself explicitly argued that its action needed to be - and was imminent, ${ }^{54}$ and many of the states that viewed the action as unlawful did so not based on a rejection of the concept of preventative action as such but because the reactor posed no imminent threat of attack to Israel. ${ }^{55}$ In other words, the criterion of imminence can be seen as the determining legal factor.

The state practice (both in general and with reference to Osiraq in particular) can thus be read in either way. Yet, even if one accepts the expansionist view, based on an assessment of this practice, that a self-defence action can indeed be taken in response to imminent attacks, it remains necessary to consider what 'imminence' means in this context. Few commentators have engaged with this question, ${ }^{56}$ but it is a crucial one; if the lawfulness of a self-defence action is dependent on the imminence of the threat being responded to - as many claim - then it is necessary to determine what this entails in practice. As Lubell notes, ' $[\mathrm{t}] \mathrm{he}$ imminence criterion is a regular feature in discussions of anticipatory self-defence, and is usually presented as a requirement for legitimizing the action. However...there is no legal definition of this notion. ${ }^{57}$

\footnotetext{
${ }^{53}$ See, for example, the statements made in the Security Council by the representatives of Brazil: UN Doc S/PV.2281 (13 June 1981), 21; Pakistan, ibid, 32; and the Soviet Union: UN Doc S/PV.2283 (15 June 1981), 22. ${ }^{54}$ See UN Doc S/PV.2280 (12 June 1981), 44-48.

${ }^{55}$ See, for example, the views expressed by China: UN Doc S/PV.2282 (15 June 1981), 32; Ireland: UN Doc S/PV.2283 (n 53) 8-11; Sierra Leone: ibid, 53-56; and Niger: UN Doc S/PV.2284 (16 June 1981), 5. See also Anthony D'Amato, 'Israel's Air Strike against the Osiraq Reactor: A Retrospective' (1996) 10 Temple International and Comparative Law Journal 259, 261 (arguing that the Osiraq attack could never be seen as qualifying as an action meeting the Caroline formula's imminence requirement).

${ }^{56}$ Although, for a detailed examination of the issue, see Lubell (n 6).

${ }^{57}$ Ibid, 702 .
} 
It is nonetheless at least relatively clear that the notion of imminence in this context at least for those who reference it - requires a specific and identifiable threat, which is highly likely to occur. ${ }^{58}$ There must be 'an objectively verifiable, concretely imminent attack. Equally, there is not - and as a matter of logic, simply could not be - a requirement for absolute certainty that an attack will occur:

$[\mathrm{U}]$ nless states (or individuals) are claiming the clairvoyant powers to predict the future, the one thing they can never do, is claim that a future attack is certain. We are, therefore, left playing the game of probabilities and trying to settle on the notion of "certain enough" that an attack is imminent. ${ }^{60}$

There thus remains a degree of uncertainty as to the meaning of 'imminence', even for those who accept the lawfulness of anticipatory self-defence. Having said this, at least broadly speaking, it may be said that the concept requires a temporal element to the threat being responded to that falls somewhere between 1) absolute certainty of a future attack (which is impossible); and 2) a threat that is not specific, objectively verifiable and already being prepared (which would thus not be sufficiently 'imminent').

It is important to note that, amongst both states and scholars there is clearly a growing acceptance preventative action will be lawful once the point is reached where there is a specific imminent attack; a notable post-9/11 evolution in doctrine and legal opinion can be

\footnotetext{
${ }^{58}$ Ibid, $702-705$.

${ }^{59}$ Report of the Independent International Fact-Finding Mission on the Conflict in Georgia (IIFFMCG), Volume I (30 December 2008), 254.

${ }^{60}$ Lubell (n 6) 714.
} 
observed in this regard. ${ }^{61}$ This can be seen, for example, from the Report of the UN 'High Level Panel on Threats Challenges and Change' in $2004^{62}$ and the Secretary General's response to this in 2005 , entitled 'In Larger Freedom, ${ }^{63}$ both of which endorsed anticipatory action as lawful when restricted by the criterion of imminence. On this basis some argue that it is now 'widely agreed...that resort to force is...permitted in anticipatory of imminent attack. $^{, 64}$

This perhaps stretches the truth somewhat: while it is probably now the case that a majority of scholars argue that anticipatory self-defence can be lawful in response to an imminent attack, ${ }^{65}$ many writers (and, more importantly, many states) remain firmly opposed to all forms of preventative action, whether it be in response to an attack that is imminent or not. Any reading of Article 51 that allows for preventative action must necessarily be rather inventive (given that it explicitly allows for defensive force 'if an armed attack occurs'), and a review of state practice in the UN era provides an ambiguous picture as to whether

\footnotetext{
${ }^{61}$ For discussion, including references to state practice, see Ruys (n 12) 318-342. This growing consensus amongst scholars is perhaps best evidenced by the 'Chatham House Principles', Wilmshurst (ed) (n 13) 967 (unequivocally holding that '[a] State may use force in self-defence against a threatened armed attack only if that attack is "imminent"').

${ }^{62}$ UN Doc A/59/565 (2 December 2004).

${ }^{63}$ UN Doc A/59/2005 (21 March 2005).

${ }^{64}$ Matthew C Waxman, 'Regulating Resort to Force: Form and Substance of the UN Charter Regime' (2013) 24 European Journal of International Law 151, 160. See also Anthony Garwood-Gowers, 'Israel's Airstrike on Syria's Al-Kibar Facility: A Test Case for the Doctrine of Preemptive Self-Defence?' (2011) 16 Journal of Conflict and Security Law 263, 279 (noting, with a rather more suitable level of equivocalness, that '[w]hile some developing states remain opposed to such a concept, on balance state practice since $9 / 11$ indicates that customary international law now recognises a right of anticipatory self-defence that permits necessary and proportionate force to avert the threat of imminent attack').

${ }^{65}$ Lubell (n 6) 718.
} 
anticipatory self-defence is lawful today. As noted, this is a debate that is as old as the Charter, with no obvious agreement in sight. Anticipatory action is still highly controversial, certainly as a matter of hard law. Of course, to add to matters, the entrenched academic positions on this issue usually have as much to do with the policy goals of the debaters as with 'pure' legal interpretation. A reasonable case can be made for either proposition and, as such, the certainty expressed on the subject by some commentators - taking either perspective - can be a little disconcerting.

On this issue this writer therefore finds himself sitting on top of the fence along with the judges of the world court. ${ }^{66}$ What can be said is that self-defence in response to an imminent attack may be lawful at the current time, and - if it is not - trends in both practice and doctrine suggest that it may soon be.

\section{iv. Pre-Emptive Self-Defence: Responses to Non-Imminent Attacks}

In contrast, the concept of (non-imminent) 'pre-emptive self-defence' is unarguably unlawful. It is difficult to identify any credible legal basis for allowing the use force in response to nonimminent attacks. The concept of pre-emptive self-defence was, of course, famously put forward by the United States in its National Security Strategy of 2002. That document stated, inter alia, that:

We must adapt the concept of imminent threat to the capabilities and objectives of today's adversaries... The greater the threat, the greater is the risk of inaction - and the

\footnotetext{
${ }^{66}$ The ICJ has explicitly refused to pronounce on the question of the lawfulness of anticipatory self-defence on the basis that it has not been at issue before it, see Nicaragua (n 8) paras 35 and 194; and Armed Activities on the Territory of the Congo (Democratic Republic of the Congo v Uganda) (merits) [2005] ICJ Reports 168, para 143.
} 
more compelling the case for taking anticipatory action to defend ourselves, even if uncertainty remains as to the time and place of the enemy's attack. ${ }^{67}$

Pre-emptive self-defence as presented by the United States in 2002 - the so-called 'Bush doctrine' - was generally viewed as being a revolutionary understanding of self-defence, ${ }^{68}$ though in fact the concept undoubtedly existed previously. ${ }^{69}$ In any event, since 2002, the Bush doctrine has overwhelmingly been rejected by academics. ${ }^{70}$ More importantly, it has also not been supported by states: there is almost no opinio juris to suggest that force can be used against a perceived but non-imminent attack. A rather stark example of this is the categorical rejection of the notion of pre-emptive self-defence by the Non-Aligned

67 The National Security Strategy of the United States of America (September 2002), www.whitehouse.gov/nsc/nss.pdf, 15. This sentiment was then repeated, essentially unmodified, in the National Defence Strategy of the United States of America (March 2005), www.defenselink.mil/news/Apr2005/d20050408strategy.pdf , especially 9-12; and the National Security Strategy of the United States of America (March 2006), www.whitehouse.gov/nsc/nss/2006/nss2006.pdf, 18 and 23.

${ }^{68}$ Christine Gray, "The US National Security Strategy and the New "Bush Doctrine" on Pre-Emptive SelfDefence' (2002) 1 Chinese Journal of International Law 437, 437 (arguing that the position on the law on the use of force presented by the 2002 National Security Strategy was 'stark and revolutionary').

${ }^{69}$ See Gazzini (n 13) 200.

70 See, for example, Garwood-Gowers (n 64) 275-279; Gazzini (n 13) 221; Christopher Greenwood, 'International Law and the Pre-Emptive Use of Force: Afghanistan, Al-Qaida, and Iraq' (2003) 4 San Diego International Law Journal 7, 12-16; Henderson (n 38) particularly at 192-193; Heiko Meiertöns, The Doctrines of US Security Policy: An Evaluation under International Law (Cambridge University Press, 2010), particularly at 221-224; and Shah (n 37) 115-119. Though, of course, some scholars have taken the opposite view: see John Yoo, 'International Law and the War in Iraq' (2003) 97 American Journal of International Law 563, especially 571-574; and Abraham D Sofaer, 'On the Necessity of Pre-Emption' (2003) 14 European Journal of International Law 209. 
Movement in the declaration that emerged from that organisation's fourteenth summit in Havana in September 2006 (an organisation with 114 state members at the time). ${ }^{71}$

It is apparent that when preventative self-defence claims are put forward, accepted or not, they are generally accompanied by assertions, by the states making them, that the threat of attack being responded to was of an imminent nature, and are - at least sometimes assessed on those terms by other states. In contrast, on the rare occasions, post-9/11, when states have claimed that self-defence against a non-imminent attack is lawful this has generally been advanced in the abstract, without being tied to any particular instance of state practice. ${ }^{72}$ Nonetheless, such claims have been criticised by other states. It may therefore be said that anticipatory self-defence is controversial but may well be lawful, whereas preemptive self-defence is, quite simply, unlawful.

\footnotetext{
${ }^{71} 14$ th Summit of Heads of State or Government of the Non-Aligned Movement, Final Document, Havana (1116 September 2006), NAM 2006/Doc.1/Rev.3,
} http://namiran.org/Files/14thSummit/Final+Document+(NAM+2006-Doc.1-Rev.3).pdf, particularly at para 22.5 (where the members of the NAM stated that they '[o]ppose and condemn...the adoption of the doctrine of preemptive attack').

${ }^{72}$ A fact highlighted by the decision of the United States to justify the 2003 intervention in Iraq based upon Security Council authorisation: see UN Doc S/2003/351 (21 March 2003). Having said this, the United States did also allude to the notion of pre-emptive self-defence in addition to the claim of Security Council authorisation. Nonetheless, the present author would argue that in legal terms, the United States offered a justification of Security Council authorisation, though it additionally employed self-defence arguments in the political arena, as well as reserving the right to act in self-defence in international law. On this point see Dino Kritsiotis, 'Arguments of Mass Confusion' (2004) 15 European Journal of International Law 233, particularly at 241. The United Kingdom and Australia, of course, chose to justify the intervention in Iraq by exclusive reference to Security Council authorisation: see UN Doc S/2003/350 (20 March 2003); and UN Doc S/2003/352 (20 March 2003), respectively. 


\section{v. Interceptive Self-Defence: Responses to Attacks that are Underway}

A final 'category' of preventative action that must briefly be noted is the concept of 'interceptive self-defence', a term coined by Yoram Dinstein. ${ }^{73}$ This concept is intended to distinguish responses against imminent or non-imminent attacks from actions taken against attacks that are already underway (albeit that their injurious consequences have not yet occurred). This notion would apply to, for example, a missile defence system destroying missiles that have already been launched against the defending state. ${ }^{74}$ One might perhaps therefore think of interceptive self-defence as the response to 'extremely imminent attacks'.

Such action in self-defence is unquestionably lawful, to the point that little further discussion is required. ${ }^{75}$ That is except to say that the present author wonders how much, conceptually, the notion of 'interception' actually adds to the debate. ${ }^{76}$ Where an attack is underway and irrevocable, it can fairly uncontroversially be viewed as falling within the meaning of an armed attack occurring, as per Article 51. Few would argue that a verified, launched strike is not yet 'an attack' because it has not yet hit. ${ }^{77}$ So, while the notion of 'interceptive self-defence' has some intuitive appeal, it in fact represents an attack that is so imminent that it is simply an attack per se; meaning that the notion unnecessarily adds to the plethora of terms and concepts already populating the self-defence timeline. ${ }^{78}$

\footnotetext{
${ }^{73}$ Dinstein (n 11) 203-205.

${ }^{74}$ Ruys (n 12) 253.

${ }^{75}$ Ibid, 264-266.

${ }^{76}$ See Lubell (n 6) 704-705 (taking the same view).

${ }^{77}$ Indeed, Dinstein himself notes that '[i]nterceptive self-defence is lawful, even under Article 51 of the UN Charter, for it takes place after the other side has committed itself to an armed attack..., Dinstein (n 11) 204, emphasis added and citations omitted.

78 Tibori Szabó (n 4) 197-198.
} 


\section{During THE AtTACK: THE TIMELINESS OF THE RESPONSE}

Having considered the ratione temporis dimension of self-defence in the period before the attack, and thus the controversial question of preventative action, we now turn to temporal restrictions in relation to the time period during the attack being responded to. This is the question of the timeliness of the response, or what is sometimes termed the 'immediacy' of or (conversely) the 'delay in' - the defensive use of force.

\section{i. The Need for an 'Immediate' Response}

In the uncontroversial situation of an action in self-defence taken in response to an actual attack, state practice indicates that there is still a need for temporal proximity: however, this concerns the temporal proximity of the response rather than of the threat being responded to. There is a long-standing general requirement that 'action in self-defence must immediately follow upon the start of an attack. ${ }^{79}$ The roots of this element of justifiable self-defence stem back to the early Christian natural law theorists. ${ }^{80}$ One can extrapolate this too from the Caroline formula, in that if the response is not immediate, then this indicates that the need to respond was not 'instant and overwhelming', and that there was in fact a 'moment for deliberation' ${ }^{81}$

In the UN era, some writers have seemingly viewed the requirement of a timely response as a standalone customary criterion for lawful self-defence. ${ }^{82}$ However, it actually

\footnotetext{
${ }^{79}$ Gamal M Badr, 'The Exculpatory Effect of Self-Defence in State Responsibility' (1980) 10 Georgia Journal of International and Comparative Law 1, 25. See also Dinstein (n 11) 233-234; and Williamson (n 25) 116-117.

${ }^{82}$ See Yoram Dinstein, 'Implementing Limitations on the Use of Force: The Doctrine of Proportionality and Necessity: Remarks' (1992) 86 American Society of International Law Proceedings 54, 57; Kevin C Kenny,
} 
forms a key aspect of the dual customary requirements of necessity and proportionality (and particularly of the necessity criterion). Excessively tardy responses will likely be interpreted as indicating that there was no genuine immediate need to respond, and thus that the response was unnecessary: if a state can wait before it responds with force, this is indicative of a lack of compelling necessity. Indeed, a 'long delay between the initial use of force and the response...is characteristic of the will to punish, ${ }^{, 83}$ which would suggest that the response constituted an unlawful 'armed reprisal'. ${ }^{84}$

'Self-Defence', in Rüdiger Wolfrum and Christiane Philipp (eds), United Nations: Law, Policies and Practice, Volume II (Martinus Nijhoff, 1995), 1162, 1167-1168; Gazzini (n 13) 143-146; and Constantinou (n 13) 157.

${ }^{83}$ Jean Combacau, 'The Exception of Self-Defence in UN Practice', in Antonio Cassese (ed), The Current Legal Regulation of the Use of Force (Martinus Nijhoff, 1986), 9, 28.

${ }^{84}$ Armed reprisals in response to a prior attack almost unquestionably constitute unlawful uses of force. See Roberto Barsotti, 'Armed Reprisals' in Antonio Cassese (ed), The Current Legal Regulation of the Use of Force (Martinus Nijhoff, 1986) 79, particularly at 81; Derek W Bowett, 'Reprisals Involving Recourse to Armed Force' (1972) 66 American Journal of International Law 1; Shane Darcy, 'Retaliation and Reprisal' in Marc Weller (ed), The Oxford Handbook of the Use of Force in International Law (Oxford University Press, 2015) 879, 886-91; Michael J Kelly, 'Time Warp to 1945: Resurrection of the Reprisal and Anticipatory Self- Defence Doctrines in International Law' (2003-2004) 13 Journal of Transnational Law and Policy 1, 12; and William V O'Brien, 'Deterrence and Self-Defense in Counterterror Operations' (1989-1990 30 Virginia Journal of International Law) 421, 426-469 (specifically setting out state practice to support the unlawfulness of armed reprisals). The commonly advanced distinction between (lawful) self-defence and (unlawful) armed reprisals is that the former is based on defensive motives, while the latter is intended to be punitive or retaliatory. See, for example, Gazzini (n 13) 163; and Barry Levenfeld, 'Israel's Counter-Fedayeen Tactics in Lebanon: SelfDefence and Reprisal Under Modern International Law' (1982-1983) 21 Columbia Journal of Transnational Law 1, 37. Having said this, the present author has elsewhere argued that the distinction between self-defence and armed reprisals is more helpfully assessed by reference to the fact that reprisals simply do not meet the objective criteria for lawful self-defence, rather than basing this on the subjective 'intention' of the state 
The need for an immediate response once an armed attack has occurred has been confirmed by the ICJ, which reached the conclusion in the Nicaragua case that the actions of the United States could not be seen as necessary, inter alia, because the measures taken vis-àvis the contras were only instigated months after the armed opposition in El Salvador had been repulsed. ${ }^{85}$ The Court thus explicitly linked the necessity criterion to the timeliness of the response taken following an actual attack. States also seemingly view this idea of the 'immediacy' of the response taken through the prism of the requirement of necessity. For example, the 1986 attacks by South Africa against alleged African National Congress (ANC) bases were criticised by other states as being unnecessary because there had been no attacks by the ANC in or against South Africa in the weeks immediately preceding the action. ${ }^{86}$

\section{ii. Contextualising the Immediacy of Response}

Identifying the notion of the need for a response in self-defence to be temporally linked to the attack it is responding to, as an aspect of the necessity criterion, is fairly straightforward: few states or scholars would deny that there must be a relatively 'close proximity in time' between the occurrence of an armed attack and the defensive response. ${ }^{87}$ However, the question of what is (or will be) viewed as 'sufficiently proximate' is highly context-specific.

In the case of the Falklands, for example, a period of twenty three days has commonly been seen as an acceptable time delay following Argentina's invasion. ${ }^{88}$ This acceptance

concerned. James A Green, 'Self-Defence: A State of Mind for States?' (2008) 55 Netherlands International Law Review 181.

${ }^{85}$ Nicaragua (n 8) para 237.

${ }^{86}$ New York Times (20 May 1986), A1.

${ }^{87}$ Constantinou (n 13) 159.

${ }^{88}$ Michael J Levitin, 'The Law of Force and the Force of Law: Grenada, the Falklands, and Humanitarian Intervention’ (1986) 27 Harvard International Law Journal 621, 638; and Tibori Szabó (n 4) 153-155. 
may have simply been due to the fact that following the initial Argentine attack there was a continued occupation of the islands, which, on one assessment, could be perceived as an ongoing armed attack. As such, one may take the view that the British need to respond remained compelling. ${ }^{89}$ It may also have been the case that the acceptability of such a delay was due in part to the scale of the necessary response. Time was needed to mobilise a force of a size suitable to meet the necessity of response required by Argentina's attack. Another possible factor in the time delay may have been the geographical location of the islands. As Rosalyn Higgins has rightly pointed out, geographical location will necessarily affect how quickly a state responds in self-defence. ${ }^{90}$ To take another example, assuming that Operation Desert Storm was an action taken in collective self-defence, ${ }^{91}$ a period of five months elapsed between the initial attack against Kuwait and the (lawful) response in self-defence. ${ }^{92}$ Again, though, there was continued occupation of Kuwait during this period. ${ }^{93}$

Finally, one might point to the United States' military strikes against the Iraqi intelligence headquarters in Baghdad on 26 June 1993. The United States asserted that these strikes were lawful actions of self-defence, taken in response to the uncovered assignation plot against (already former) President George H W Bush, while on a state visit to Kuwait

\footnotetext{
${ }^{89}$ Eric PJ Myjer and Nigel White, 'The Twin Towers Attack: An Unlimited Right to Self-Defence?' (2002) 7 Journal of Conflict and Security Law 5, 8.

${ }^{90}$ Higgins (n 19) 241. See also Tibori Szabó (n 4) 154-155.

${ }^{91}$ It contestable as to whether the legal basis for the coalition action in the Gulf was truly a measure of selfdefence, but the United States was certainly explicit that the action was taken under Article 51, see UN Doc S/21537 (16 August 1980). This is supported by the fact that the coalition forces were not permitted to use to UN flag during combat (unlike in Korea in 1950), and that Security Council Resolution 661 (6 August 1990) conspicuously reaffirmed the right of individual and collective self-defence.

92 Kenny (n 82) 1167.

${ }^{93}$ Ibid (noting this as a contributing factor to the acceptance of the operation).
} 
City. ${ }^{94}$ The plot was foiled on 14 April 1993, some two months earlier. However, despite this delay, a majority of other states took the view that the action by the United States was a lawful action of self-defence. ${ }^{95}$ Amongst those states that saw the strikes as being lawful, a number were clear that a key reason that they did so was because of the evidence produced by the United States indicating the responsibility of the Iraqi government for the plot. ${ }^{96}$ Unsurprisingly, however, it took time for the United States to acquire and assess this crucial evidence. Therefore, as Kritsiotis argued:

It would thus appear that the "immediacy" requirement was satisfied in the sense that the Clinton administration waited until it was in full command of all the available evidence and until it was entirely confident with the weight of the evidence that the Iraqi government, at its highest levels, had played a significant role in the formulation and sponsorship of the assassination plot. The wait for corroborative evidence by the Clinton administration explains why the attack was not "immediate" in the sense that the interval between the planned assassination and the missile strike was well over two months. However, it is significant to note that once the Clinton administration was

\footnotetext{
${ }^{94}$ See UN Doc S/PV.3245 (27 June 1993), 3-9.

${ }^{95}$ See, for example, ibid, for the views of France, 13; Japan, 16; Brazil, 18, Hungary, 18; the United Kingdom, 22; Russia, 22; and New Zealand, 23. See also Ruys (n 12) 202-203. Although, it is worth noting that this support was not unanimous: within the Security Council, see, for example, the view expressed by China, UN Doc S/PV.3245 (n 94) 21; and, elsewhere, see, for example, the view of Egypt, 'Arab Governments Critical' New York Times (28 June 1993), A5.

${ }^{96}$ See UN Doc S/PV.3245 (n 94), as asserted by France, 13; Japan, 16; and Brazil, 18. See also Alan D Surchin, 'Terror and the Law: The Unilateral Use of Force and the June 1993 Bombing of Baghdad' (1994-1995) 5 Duke Journal of Comparative and International Law 457, 467.
} 
seized with sufficient evidence, there was no delay in deciding upon the appropriate response or in effecting its execution. ${ }^{97}$

Thus, some measure of temporal connection is required between an armed attack and the response to it; determining how proximate that connection should be, however, is rather more difficult. The need for an 'immediate' response appears to be extremely flexible, perhaps even more so than the application of the general criteria of necessity and proportionality. Certainly it may be said that the requirement to act promptly is not absolute, and will depend on the context of the situation. Indeed, given that an attempt to negotiate goes a long way towards establishing necessity, ${ }^{98}$ if a state first tries to negotiate and then finds that it must nonetheless resort to force to defend itself following the failure of those negotiations, the time delay will not mean that the state falls foul of this temporal restriction. ${ }^{99}$

Therefore, 'while immediacy serves as a core element of self-defence, it must be interpreted reasonably., 100 The response must thus be 'timely' in the sense that it must be taken within reasonable temporal proximity, taking into account all the circumstances of the particular case: the difficulty of evidence gathering, the delay incurred though the mobilisation of the responding state's own forces, the time taken in attempts at negotiation, and so on. Put differently, the state is allowed a 'reasonable window of time' to respond. ${ }^{101}$

\section{After the Armed AtTaCK: When MUST THE ReSPOnSE End?}

\footnotetext{
${ }^{97}$ Dino Kritsiotis, 'The Legality of the 1993 US Missile Strike On Iraq and the Right of Self-Defence in International Law' (1996) 45 International and Comparative Law Quarterly 162, 169.

${ }^{98}$ See (n 26) and accompanying text.

${ }^{99}$ Dinstein (n 82) 57.

${ }^{100}$ Gill (n 7) 154.

${ }^{101}$ Dinstein (n 11) 267.
} 
The final point on the timeline of self-defence relates to the period after the end of the attack being responded to. The traditional rule here is that defensive action will be lawful only up until the point at which the attack being responded to (or the injurious consequences of it, such as the occupation of territory) has been abated. ${ }^{102}$ Broadly speaking, once the armed attack is over, any defensive response must also be stopped.

\section{i. The 'Until Clause' in Article 51}

In the context of Article 51 of the UN Charter, it will be recalled that measures in selfdefence are only valid 'until the Security Council has taken measures necessary to maintain international peace and security'. ${ }^{103}$ Under this 'until clause', a victim state is required to desist in its forcible action once the Security Council has taken 'necessary measures'. It has been argued by a number of states that the defending state is only required to desist where the Council adopts 'effective' measures to end the attack (i.e., that only 'effective' measures will be suitably 'necessary' for this element of Article 51 to kick in). ${ }^{104}$ This makes a degree of conceptual sense in that a state's inherent right of self-defence must surely remain unfettered until the Security Council has effectively stepped in to abate the defensive necessity. ${ }^{105}$

\footnotetext{
${ }^{102}$ See Corten (n 13) 486-487; and Moir (n 11) 55-59.

${ }^{103}$ UN Charter, Article 51.

${ }^{104}$ For example, the United Kingdom argued in the context of the Falklands conflict that the until clause 'can only be taken to refer to measures which are actually effective to bring about the stated objective,' see UN Doc S/15016 (30 April 1982).

${ }^{105}$ For discussion, see Greig (n 32) particularly at 389-390; and Erika de Wet, The Chapter VII Powers of the United Nations Security Council (Hart Publishing, 2004), 263-264.
} 
However, the exact obligation with regard to Security Council oversight of selfdefence is not entirely clear, ${ }^{106}$ and it is beyond the scope of this article to consider what action by the Council may be seen as constituting 'necessary' measures. It may certainly be said that 'if the Council's action results in removing the necessity for the exercise of selfdefence, there would be no legal basis for continuing its exercise. ${ }^{, 107}$ What is perhaps less clear is whether this is also the case where the Council takes measures that do not entirely remove that necessity (or, at least, do not do so in the eyes of the state invoking self-defence). In any event, it is worth noting that - in most cases - this limitation will not come into play, because the Council only rarely involves itself in ongoing self-defence actions (even in its more 'enlightened' post-Cold War incarnation). ${ }^{108}$ Nonetheless, the 'until clause' in Article 51 certainly strengthens the notion that self-defence actions have an inherently limited lifespan.

\section{ii. The Customary Requirement that Responses do not Outlast Attacks}

More important than the 'until clause' is the basic customary international law requirement that self-defence is lawful only while the armed attack is ongoing. This requirement again blurs the line between necessity and proportionality: it can be seen as forming part of both criteria. In the context of necessity criterion, it cannot be 'necessary' to continue to respond

\footnotetext{
${ }^{106}$ On the controversy over the exact meaning of Article 51's 'until clause', see Gray (n 3) 104-105; Christopher Greenwood, 'New World Order or Old - The Invasion of Kuwait and the Rule of Law' (1992) 55 Modern Law Review 153, 164; Greig (n 32) 389-399; Malvina Halberstam, 'The Right to Self-Defence Once the Security Council Takes Action' (1996) 17 Michigan Journal of International Law 229; and Higgins (n 45) 205-207.

107 Terry D Gill, 'When Does Self-Defence End?' in Marc Weller (ed), The Oxford Handbook of the Use of Force in International Law (Oxford University Press, 2015) 735, 747.

${ }^{108}$ Greig (n 32) 390-391.
} 
in self-defence once there is no longer an attack to respond to. ${ }^{109}$ The idea that the necessity element of self-defence requires action to end when the attack does is a longstanding one. For example, while Daniel Webster himself did not refer to this idea in the Caroline correspondence, Lord Ashburton argued in his reply of 28 July 1842 that, in relation to the principle of respect for territorial integrity:

[I]t is admitted by all writers, by all jurists, by the occasional practice of all nations, not excepting your own, that a strong overpowering necessity may arise when this great principle may and must be suspended. It must be so, for the shortest possible period during the continuance of an admitted overruling necessity. ${ }^{110}$

The notion that a response will fall foul of the necessity criterion when it continues beyond the abeyance of the attack it is responding to also forms an aspect of UN era practice. For example, in the context of the Mayaguez incident, the United States delivered a message to the Cambodian government stating: 'As soon as you...release the crew members...we will promptly cease military operations. ${ }^{, 11}$ This limitation has been cited as evidencing the lawfulness of the action. ${ }^{112}$ A rather more recent example is the position taken by South Korea following its naval clash with the North in 2002. Here, South Korea claimed that it

\footnotetext{
${ }^{109}$ Badr (n 79) 25-26; Constantinou (n 13) 159-161; Gill (n 107) 745; and David Kretzmer, 'Targeted Killing of Suspected Terrorists: Extra Judicial Executions or Legitimate Means of Defence?' (2005) 16 European Journal of International Law 171, 187-188

${ }^{110}$ Letter dated 28 July 1842, from Lord Ashburton to Daniel Webster (1841-1842) XXX British and Foreign State Papers 195, 198, emphasis added.

${ }^{111}$ Document reproduced in full in New York Times (16 May 1975), 15, emphasis added.

${ }^{112}$ See Major Thomas E Behuniak, 'The Seizure and Recovery of the SS Mayaguez: A Legal Analysis of the United States Claims, Part II' (1979) 83 Military Law Review 59, 87.
} 
initially responded with force against direct fire from North Korean vessels. ${ }^{113}$ However, once the incident was over, South Korea undertook a number of measures to attempt to gain reparations for the incident, but these were all of a non-forcible nature. ${ }^{114}$ It stressed that it would maintain combat-readiness, but would only use force if North Korea initiated another attack against it. ${ }^{115}$ Thus, the initial response was forcible until the attack was abated, but further measures in response were non-forcible. To the extent that there was reaction by other states to South Korea's position regarding the incident, it was positive. ${ }^{116}$

The concept of a limited duration to responses in self-defence can also be seen as forming an aspect of the proportionality criterion. Given that proportionality requires a degree of balance between the armed attack suffered and the defensive need to abate that attack, it is logical that once the attack is over any further forcible action will become disproportionate. ${ }^{117}$ A good example here is the reaction to the United States action in Grenada in 1983, so far as this was justified as an action in self-defence to protect

\footnotetext{
113 'Koreas Clash in Sea Battle', BBC News (29 June 2002), http://news.bbc.co.uk/1/hi/world/asiapacific/2073694.stm.

${ }^{114}$ See 'The Naval Clash on the Yellow Sea on 29 June between South and North Korea: The Situation and ROK's Position', press release of the Ministry of National Defence of the Republic of Korea (1 July 2002), www.globalsecurity.org/wmd/library/news/rok/2002/0020704-naval.htm, particularly at 6 .

${ }^{115}$ Ibid.

116 'Koreas Trade Blame for Naval Clash', BBC News (30 June 2002), http://news.bbc.co.uk/1/hi/world/asiapacific/2075661.stm.

${ }^{117}$ See Gill (n 107) 745-746; and Greig (n 32) 392-393.
} 
nationals. ${ }^{118}$ Here, the fact that the forces of the United States remained long after their nationals were secured was clearly viewed as a breach of the proportionality requirement. ${ }^{119}$

Similarly, the ICJ considered the notion of the duration of a response in self-defence in its application of the proportionality criterion in the Nicaragua decision. It was concluded in that case that the United States actions against Nicaragua could not be considered proportionate, in part because of the temporal distance between the claimed armed attack(s) and the response taken by the United States:

Finally on this point [the proportionality of the United States' actions], the Court must also observe that the reaction of the United States in the context of what it regarded as self-defence was continued long after the period in which any presumed armed attack by Nicaragua could reasonably be contemplated. ${ }^{120}$

The requirement that a defensive response must end when the attack that it is responding to ends therefore appears deceptively straightforward: when the measures taken - either by the Security Council, the victim state, or both - have suitably resolved the situation, then any

\footnotetext{
${ }^{118}$ The United States additionally contended that it acted in Grenada following in invitation to do so, from both the Governor-General of Grenada and the Organisation of Eastern Caribbean States, see Levitin (n 88) 645-649. 119 A representative example of the state response to the intervention with regard to the question of proportionality is the statement made by the representative of Zimbabwe in the Security Council: UN Doc S/PV.2491 (27 October 1983), 5. More generally, the views of other states as to the unlawfulness of the Grenada intervention is well evidenced by General Assembly Resolution 38/7 (2 November 1983), which condemned the intervention and labelled it 'a flagrant violation of international law'. See James A Green, 'Passportisation, Peacekeepers and Proportionality: The Russian Claim of the Protection of Nationals Abroad in Self-Defence', in James A Green and Christopher PM Waters (eds), Conflict in the Caucasus: Implications for International Legal Order (Palgrave Macmillan, 2010), 54, 61-62.

${ }^{120}$ Nicaragua (n 8) para 237.
} 
individual self-defence action must end. ${ }^{121}$ The problem, of course, is identifying the point of 'suitable resolution'. ${ }^{122}$ A return to the territorial status quo ante bellum is the minimum legitimate goal for self-defence, but it is clear that states can do more than this while remaining within the bounds of necessity and proportionality. To reiterate what was said in section III.ii: the proportionality criterion does not require states to respond with an exact equivalence of scale or means. The obligation is, rather, that states cannot go beyond what is required to meet their legitimate defensive goals. ${ }^{123}$

A strict requirement for states to desist defensive force as soon as the attack being responded to is over 'unfavourably stacks the cards in favour of the aggressor,' ${ }^{124}$ in that a belligerent state could launch an armed attack knowing that the worst possible outcome for it would be a mere return to the ante bellum status quo. It is therefore clear that a defending state's troops do not need to, for example, stop at the border and watch the aggressor regroup: certain steps can be taken to endeavour to ensure that no repeat occurrence.

It is undeniable that states may take measures beyond merely repulsing an aggressor. A good example of this is the 'protection zone' maintained for five years by the United Kingdom around the Falkland Islands, which Argentinean vessels were not permitted to enter. This was clearly accepted as a lawful defensive measure. ${ }^{125}$ A rather more controversial example is Israel's seizure of territory during the Six Day War. To some extent states were supportive of Israel's action when this seemed to genuinely be securing the state

\footnotetext{
${ }^{121}$ Greig (n 32) 389.

${ }^{122}$ Kretzmer (n 27) 239.

${ }^{123}$ See (n 29) and accompanying text.

${ }^{124}$ Kretzmer (n 27) 262.

${ }^{125}$ See Christopher Greenwood, 'Self-Defence and the Conduct of International Armed Conflict', in Yoram Dinstein and Mala Tabory (eds), International Law at a Time of Perplexity: Essays in Honour of Shabtai Rosenne (Martinus Nijhoff, 1989), 273, 276.
} 
against further attacks, but once those threats had clearly been secured against, continued action was almost universally viewed as a breach of international law. ${ }^{126}$

The question is, therefore, how much further a state can go to ensure its security in self-defence. Broadly speaking, action that reasonably secures the state following an armed attack will be acceptable, whereas responses that extend well beyond the end of the armed attack - such as those leading to, but not limited to situations of, regime change - will be unlawful. ${ }^{127}$ As with the 'immediacy' requirement during an attack (a point earlier along the 'self-defence timeline', examined in section IV), the exact duration of the response that may be taken in self-defence is limited, but its limits are context specific: meaning that application of this requirement to any particular action is far from simple.

\section{iii. 'Dual' Claims: Responding to Both Past and Future Attacks}

Further muddying this already rather murky water is the trend for states to present mixture of legal argumentation, citing both 'traditional' self-defence and the more 'preventative' variety. In other words, a number of states have presented self-defence claims that combine 'continuing' responses to an armed attack that has ended with the need to respond to future attacks. This 'dual' legal argument thus returns us to preventative forms of self-defence, as discussed in section III. We saw in that section that preventative action is controversial, even - for some - in instances where an imminent attack can be identified. To alleviate that controversy, the preventative justification is here coupled with a justification based on an

\footnotetext{
${ }^{126}$ See, for example, statements made by India: UN Doc S/PV.1352 (9 June 1967), 43-45; and Bulgaria: UN Doc S/PV.1353 (9 June 1967), 67-70.

${ }^{127}$ See, for example, the international response to El Salvador's occupation of Honduras (1969); the Indian intervention in East Pakistan (1971); the United States action in Grenada (1983); and the United States action in Panama (1989), all of which were in the main condemned.
} 
armed attack that has already occurred (but is over). States making such 'circular', 128 arguments (circular in the sense that they in part return us to an earlier point on our timeline) are therefore hoping that two controversial self-defence claims, taken together, will form an uncontroversial one.

While this type of 'dual' claim has been made fairly commonly both pre- and post$9 / 11$, with differing degrees of success, ${ }^{129}$ the most high profile example of this approach remains the United States led intervention in Afghanistan in 2001. Here, the United States argued that action was taken '[i]n response to these attacks [of 9/11]' but also that it was 'designed to prevent and deter further attacks on the United States.' ${ }^{130}$ On this basis, some commentators saw Operation Enduring Freedom as being lawful both as a response to an armed attack, and as an anticipatory action in relation to future attacks. ${ }^{131}$ The intervention in Afghanistan was, of course, generally viewed as being a lawful exercise of the right of selfdefence at the time by states and scholars alike, ${ }^{132}$ although it has come under increasing

\footnotetext{
${ }^{128}$ Tibori Szabó (n 4) 242-243.
}

${ }^{129}$ Ibid, 155-162 (examining a number of examples: The bombing of a Yemeni Fort by the United Kingdom (1964); The Gulf of Tonkin Incident (1964); The United States bombing of Libya (1986); and the United States attack against Iraq (1993); and the Russia/Georgia conflict (2008)). There are other examples dating from even earlier in the UN era. See, for example, Pakistan's claim that its Kashmir operation of 1948 was both a preventative action and a response to a previous Indian 'act of aggression', UN Doc S/PV.464 (8 February 1950), 1-31.

${ }^{130}$ UN Doc S/2001/946 (7 October 2001).

${ }^{131}$ Barry A Feinstein, 'Operation Enduring Freedom: Legal Dimensions of an Infinitely Just Operation' (2001 2002) 11 Journal of Transnational Law and Policy 201, 282; and Greenwood (n 70) 23.

${ }^{132}$ Operation Enduring Freedom was explicitly condoned in 2001 by Russia, China, Pakistan, Japan, the United Arab Emirates and Saudi Arabia, as well as by nineteen NATO States. Offers of direct military assistance to the United States came from the United Kingdom, Australia, Canada, Singapore, Spain, Turkey, Ukraine, Romania, Portugal, New Zealand, the Netherlands, Germany, Italy, Jordan, Belgium, Denmark, France and South Korea 
academic criticism more recently, in part on the basis that the armed attack being responded to was over well before it was initiated. ${ }^{133}$

It is admittedly 'not always practical to talk about strictly anticipatory action or strictly remedial action in self-defence, because the two dimensions can be intrinsically interconnected.' 134 While forcible action taken in response to an attack that is clearly 'over' may look rather disconcertingly like a purely punitive measure of reprisal (which of course would be unlawful), ${ }^{135}$ in fact this may not always be the case. ${ }^{136}$ There may indeed be a genuine need to preventatively respond to future attacks.

Ultimately, the acceptability of any 'dual' claim of responding both to an attack that occurred but is over and the threat of future attacks - as with all claims of self-defence depends on the reasonableness of that claim. Just as with preventative self-defence per se,

(collated by the United States Department of State, www.state.gov/s/ct/rls/fs/2001/5194.htm and the United Kingdom Parliament, www.parliament.uk/commons/lib/research/rp2001/rp01-081.pdf, 31). See also Security Council Resolution 1368 (12 September 2001); Security Council Resolution 1373 (28 September 2001); Sean D Murphy (ed), 'Contemporary Practice of the United States Relating to International Law' (2002) 96 American Journal of International Law 237, especially 248; and Michael J Kelly, 'Understanding September 11th - An International Legal Perspective on the War in Afghanistan' (2001-2002) 35 Creighton Law Review 283, 285286.

${ }^{133}$ For an excellent appraisal, see Williamson (n 25) particularly at 161-231. Similarly, it is also probably true that the general acceptance of the Afghanistan intervention by other states at the time was largely political, not legal. As such, Operation Enduring Freedom can perhaps be viewed as something of a sui generis case. See John Quigley, 'The Afghanistan War and Self-Defence' (2002-2003) 37 Valparaiso University Law Review 541, 554.

\footnotetext{
134 Tibori Szabó (n 4) 156.

${ }^{135}$ See (n 84).

${ }^{136}$ Kretzmer (n 27) 254.
} 
the question of reasonableness will largely turn on the question of imminence. ${ }^{137}$ If there is a genuine and demonstrable threat of imminent further attack, then the claim that it is necessary to respond to this threat with force will of course be significantly stronger where an armed attack has already been perpetrated by the same aggressor. ${ }^{138}$ Few would deny the right of a state to respond in such circumstances. Indeed, when the identified future threat is coupled with the indisputable fact that an actual attack has already occurred, the 'imminence' requirement is likely to be rather more loosely interpreted. ${ }^{139}$ Nonetheless, responses to vaguely perceived future threats, even when they follow a previously concluded attack, are unlikely to gain much traction within the international community. To allow states - even once attacked - a right to pre-emptively respond to any possible perceived future threat 'would seem to give them too much leeway.' 140

The default position therefore remains that '[a]rmed force used in self-defence typically [must have a] defined objective to reverse the armed attack, such as driving a foreign army back to a certain line, ${ }^{, 141}$ albeit that this must be interpreted so as to allow the exercise of self-defence to extend to limited measures to disable the enemy to the point that it cannot simply rest, regroup and resume.

\section{CONCLUSION}

${ }^{137}$ Michael N Schmitt, 'Counter-Terrorism and the Use of Force in International Law' (2002) 5 The Marshall
Center Papers, The George C Marshall European Center for Security Studies, www.marshallcenter.org/mcpublicweb/MCDocs/files/College/F_Publications/mcPapers/mc-paper_5-en.pdf, 23-

24.

${ }^{138}$ Kretzmer (n 27) 266.

${ }^{139}$ Schmitt (n 137) 24.

${ }^{140}$ Kretzmer (n 27) 265.

${ }^{141}$ Quigley (n 133) 550, emphasis added. 
This article examined what Pieter Kooijmans - former judge of the ICJ - has previously referred to as 'the seemingly illusive issue of the temporal dimension of self-defence." ${ }^{142}$ It considered three key points along the 'timeline' of self-defence: the period before an armed attack has occurred, the period while the attack in ongoing and the period after it has ended. At all three points in the conceptual lifespan of self-defence, one is confronted with controversies. The ambition of this article is modest: it does not seek to resolve such controversies, but simply to highlight them.

In relation to the period before an armed attack has occurred, it was argued that any use of force in self-defence against an attack that is not demonstrably imminent (what is herein termed 'pre-emptive self-defence') is unquestionably unlawful. There is no toleration in state practice for the 'Bush doctrine'; if states perceive temporally remote threats they are required to turn to the Security Council or employ non-forcible measures. In contrast, there is a growing consensus, amongst both states and scholars, that anticipatory action in selfdefence against an imminent attack may be lawful in strictly limited instances. The present author is not willing to assert unreservedly that the right of self-defence extends to this quite yet, given the notable and continuing opposition to the concept, but all the indications are that if it does not at the present time, it will do so soon.

Turning to the question of action taken during an ongoing armed attack, the temporal restriction here is on the victim responding within reasonable temporal proximity to the commencement of the attack against it. Overly tardy responses will be considered disingenuous (read: unnecessary, in self-defence speak) and thus will be unlawful. However, there is significant leeway for states as to what will be considered a 'reasonable' timeframe for response, based on a context-specific appraisal of the various factors that may delay a

\footnotetext{
${ }^{142}$ Pieter H Kooijmans, foreword in Tibori Szabó (n 4) vii.
} 
self-defence action: intelligence gathering, initial resort to negotiation, geographical disparity, and so on.

Finally, it was argued that responses that occur after an armed attack has ended will, in general, be unlawful. This claim must be tempered by two further points, however. First, states certainly can, to a limited degree, extend their response in self-defence beyond the moment where the attack being responded to terminated. States can unquestionably take further reasonable steps to ensure their security. Secondly, self-defence actions taken in response to armed attacks that have occurred but ended may be justified (or avowedly justified) by a 'dual' argument, combining the need to respond to the previous attack with the need to respond to a future attack. As with preventative self-defence per se, where the future attack in such a scenario is imminent, the overall self-defence claim may indeed be legally acceptable. Nonetheless, these 'dual' self-defence claims - even where the future attack is imminent - are far from uncontroversial.

Taking into account these various conclusions, the self-defence timeline as set out in this article is illustrated by Figure 1. 
Figure 1: The Timeline of Self-Defence

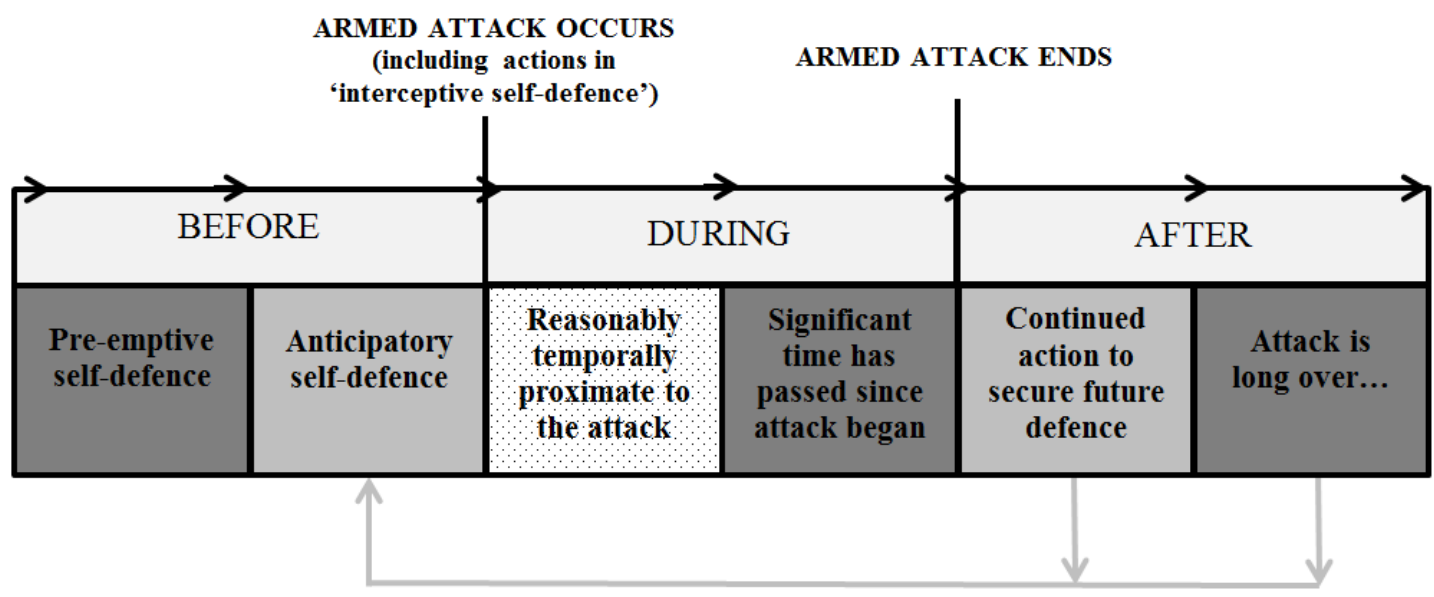

'Dual' argumentation / ongoing threat...

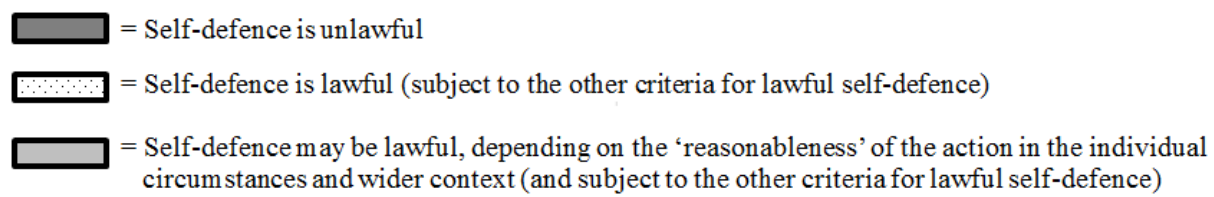

While Figure 1 is useful in highlighting the crucial points at which temporality is a determining factor in the lawfulness of a self-defence action, its true value, of course, is that is demonstrates just how problematic the application of the temporal limitations on selfdefence are. In reality the use of military force will rarely - if ever - fall into such neat boxes. For example, the line between what is 'reasonably temporally proximate to the attack' and what constitutes a 'significant amount of time since the attack began' is, as we have seen, almost impossible to identify. Similarly, determining what actions will be viewed as falling into the 'continued action to secure defence' box with any degree of certainty is an extremely difficult exercise. Nonetheless, Figure 1 as least provides us with an indication of the key points of contention during the lifespan of self-defence.

As a concluding thought, it is worth noting that the issues discussed in this article are underpinned by increasing claims in the literature that the temporal elements of self-defence are illogical in the context of the modern world; or, at least, that they may need serious 
rethinking. ${ }^{143}$ The temporal aspects of the customary international law on self-defence have been seen, by many, through the (potentially dangerously distorting) lens of twenty-first century terrorism. ${ }^{144}$ The difficulty in detecting imminent terrorist attacks (or the risk of waiting for threats to cross the imminence threshold), the need to gather information with regard to terrorist activities before responding and the difficulties of mounting an immediate response to such attacks, all mean that the three temporal elements discussed in this article are under significant strain.

In this context, the various temporal restrictions upon self-defence have almost certainly become more flexible. Indeed, long before the emergence of modern terrorism ever since the advent of nuclear weapons - some level of flexibility with regard to temporal proximity is the only logical way that self-defence can be understood. ${ }^{145}$ This 'flexibility' has arguably increased still further since $9 / 11$, in terms of what states will deem to be legally acceptable. When we consider state practice, however, it is clear that states still acknowledge the need for various temporal links between a response in self-defence and the attack being responded to. It is certainly not the case that such temporal safeguards have disappeared

\footnotetext{
${ }^{143}$ See, for example, Maria B Occelli, 'Sinking the Caroline: Why the Caroline Doctrine's Restrictions on SelfDefence Should Not be Regarded as Customary International Law' (2003) 4 San Diego International Law Journal 467, 483-488; and Gregory M Travalio, 'Terrorism, International Law, and the Use of Military Force' (2000) 18 Wisconsin International Law Journal 145, 164-166.

${ }^{144}$ This argument is not - strictly speaking - new, in that it has been stressed in relation to the unique nature of nuclear weapons since the inception of such armaments. Israel made this point before the Security Council with regard to its action against the Osiraq reactor, UN Doc S/PV.2280 (n 54) 53-55. See also Bowett (n 32) 191192.

145 See Higgins (n 19) 242 ('in a nuclear age, common sense cannot require one to interpret an ambiguous provision in a text in a way that requires a state to passively accept its fate before it can defend itself').
} 
Forthcoming in the Journal on the Use of Force and International Law, 2(1), 2015

from customary international law altogether; nor is it that they have been reframed to the point of entirely losing their restrictive value. 